\title{
Decremental PEEP Titration: A Step Away From the Table
}

The setting of PEEP in patients with ARDS has become a standard of practice for nearly 46 years. ${ }^{1}$ One of the more widely used methods in current practice for PEEP selection is the ARDS Network PEEP/F $\mathrm{IO}_{2}$ table. ${ }^{2}$ This table guides the clinician to increase or decrease PEEP and $\mathrm{F}_{\mathrm{IO}_{2}}$ based on oxygenation. The low-to-modest levels of PEEP utilized throughout the table have been challenged in 2 studies that randomized patients to receive mechanical ventilation with $6 \mathrm{~mL} / \mathrm{kg}$ of tidal volume $\left(\mathrm{V}_{\mathrm{T}}\right)$ with the traditional PEEP table or a higher PEEP table. ${ }^{3,4}$ These studies failed to demonstrate an improvement in clinical outcomes. A systematic review and meta-analysis of high PEEP in ARDS published in RESPIRATORY CARE found no improvement in 28 day mortality. ${ }^{5}$ The meta-analysis raised some interesting points related to PEEP selection methods used in the included studies; most intriguing is that perhaps using a table to set PEEP has the potential to worsen ventilator-induced lung injury in some patients, rather than provide benefit. Currently, the appropriate level and best methods to select PEEP for ARDS remain unclear. This uncertainty should not discourage PEEP studies, rather it should encourage clinicians to study methods of selecting PEEP based on variables other than oxygenation guided by a table.

\section{Decremental PEEP Titration}

The study by Rodriguez and colleagues in this issue of RESPIRATORY CARE monitored $\mathrm{P}_{\mathrm{aO}}$, ratio of dead space $\left(\mathrm{V}_{\mathrm{D}}\right)$ to $\mathrm{V}_{\mathrm{T}}$, respiratory-system compliance $\left(\mathrm{C}_{\mathrm{RS}}\right)$, and transpulmonary pressure $\left(\mathrm{P}_{\mathrm{tp}}\right)$ during a decremental PEEP titra-

See the Original Study on Page 754

tion. ${ }^{6}$ The goal of the decremental PEEP titration is to determine the level of PEEP required to maintain an open lung after lung recruitment. This is not a new approach to determining an optimal level of PEEP..$^{7-12}$ However, a quick look at the available evidence may leave clinicians questioning the usefulness of this method. In the provided Table of decremental PEEP studies there are noticeable differences in titration methods, monitored values, methods for prior recruitment, as well as what the "optimal" level of PEEP should be post procedure. Also, only one randomized controlled trial was powered for mortality, and there was no difference in clinical outcomes. ${ }^{9}$ It should be noted that the timing between PEEP changes in the randomized controlled trial was 30 seconds, which was shorter than any other study in the table. When gas exchange is the target for optimizing PEEP, the time spent at each level becomes increasingly important. ${ }^{13}$ The study by Rodriguez and colleagues titrated PEEP every $3 \mathrm{~min}$; it is discussed as a potential limitation to the study. ${ }^{6}$

\section{Transpulmonary Pressure and PEEP}

The use of transpulmonary pressure to set PEEP is an interesting concept, with encouraging data, but requires further study. It uses the esophageal pressure as a surrogate for pleural pressure. Luckily, the methods for measurement are very consistent in the literature, and despite its potential limitations, it appears to be a valuable tool. ${ }^{14-17}$ One concern that is frequently mentioned is the positional artifact associated with measurements. Previous work has demonstrated a difference in esophageal pressure between upright and supine positions. ${ }^{18}$ This was done with healthy volunteers, and for this reason positional artifact was not compensated for in this study. We also do not compensate for position in our ICU for this reason.

\section{Transpulmonary Pressure-Inspiratory}

The level of inspiratory $\mathrm{P}_{\mathrm{tp}}$ (lung stress) that occurs during a decremental PEEP titration, as observed in this study, is of particular concern. These values, combined with the length of time required to perform such maneuver, may influence your use of this approach for setting PEEP. However, the starting PEEP level in this study was $30 \mathrm{~cm} \mathrm{H}_{2} \mathrm{O}$. Another point of interest for some may be the finding that the level of airway pressure with the highest sensitivity and specificity for excessive inspiratory $\mathrm{P}_{\mathrm{tp}}$ (lung stress) was $37 \mathrm{~cm} \mathrm{H}_{2} \mathrm{O}$. Other research supports the notion that airway pressure is an inadequate surrogate for lung stress and strain. ${ }^{19}$ This is important because many protocols related to mechanical ventilation aimed at an absolute limit of $30 \mathrm{~cm} \mathrm{H}_{2} \mathrm{O}$ of plateau pressure may lead to unnecessary use of rescue therapies with patients. ${ }^{20}$ An endinspiratory $\mathrm{P}_{\mathrm{tp}}>18 \mathrm{~cm} \mathrm{H}_{2} \mathrm{O}$ significantly increased $\mathrm{V}_{\mathrm{D}} / \mathrm{V}_{\mathrm{T}}$ in this study, regardless of airway pressure. Although a 
Decremental PeEP Titration: A Step Away From the Table

Table. Decremental PEEP Studies

\begin{tabular}{|c|c|c|c|c|c|c|c|}
\hline $\begin{array}{l}\text { First } \\
\text { Author }\end{array}$ & Year & $n$ & Starting PEEP & $\begin{array}{l}\text { Decremental } \\
\text { Titration }\end{array}$ & $\begin{array}{c}\text { Value } \\
\text { Monitored }\end{array}$ & Optimal PEEP & Results \\
\hline Borges $^{7}$ & 2006 & 26 & $\begin{array}{l}25 \mathrm{~cm} \mathrm{H}_{2} \mathrm{O} \\
\text { Prior recruitment using a } \\
\text { stepwise increase of } \\
\text { pressure control to a } \\
\text { maximum of } 60 \mathrm{~cm} \mathrm{H}_{2} \mathrm{O}\end{array}$ & $\begin{array}{l}2 \mathrm{~cm} \mathrm{H}_{2} \mathrm{O} \\
\quad \text { every } 4 \mathrm{~min}\end{array}$ & $\mathrm{P}_{\mathrm{aCO}_{2}}+\mathrm{P}_{\mathrm{aO}_{2}}$ & $\begin{array}{l}\text { Lowest level } \\
\text { maintaining } \mathrm{P}_{\mathrm{aCO}_{2}} \\
+\mathrm{P}_{\mathrm{aO}_{2}} \geq 400 \mathrm{~mm} \\
\mathrm{Hg}\end{array}$ & $\begin{array}{l}\text { Oxygenation benefit was } \\
\text { maintained or increased at } \\
6 \mathrm{~h}\end{array}$ \\
\hline Girgis $^{8}$ & 2006 & 20 & $\begin{array}{l}20 \mathrm{~cm} \mathrm{H}_{2} \mathrm{O} \\
\text { Prior recruitment using } \\
\text { sustained inflation of } 40 \mathrm{~s}\end{array}$ & $\begin{array}{l}2 \mathrm{~cm} \mathrm{H}_{2} \mathrm{O} \\
\quad \text { every } 15-20 \mathrm{~min}\end{array}$ & $\mathrm{~S}_{\mathrm{pO}_{2}}$ & $\begin{array}{l}\text { PEEP level above the } \\
\text { level that caused a } \\
\text { decrease in } \mathrm{S}_{\mathrm{pO}_{2}} \text { to } \\
<90 \%\end{array}$ & $\begin{array}{l}\text { Sustained oxygenation } \\
\text { improvement for } 4 \mathrm{~h}\end{array}$ \\
\hline Gernoth $^{9}$ & 2009 & 12 & $\begin{array}{l}20 \mathrm{~cm} \mathrm{H}_{2} \mathrm{O} \\
\text { Prior recruitment using } \\
\text { pressure control to a } \\
\text { maximum of } 50 \mathrm{~cm} \mathrm{H}_{2} \mathrm{O}\end{array}$ & $\begin{array}{l}2 \mathrm{~cm} \mathrm{H}_{2} \mathrm{O} \\
\quad \text { every } 2 \mathrm{~min}\end{array}$ & $\begin{array}{l}\text { Dynamic } \\
\text { compliance }\end{array}$ & $\begin{array}{l}\text { Best dynamic } \\
\text { compliance }+2 \\
\mathrm{~cm} \mathrm{H}_{2} \mathrm{O}\end{array}$ & $\begin{array}{l}\text { Better oxygenation and lung } \\
\text { compliance; improved } \\
\text { right-ventricular function }\end{array}$ \\
\hline $\begin{array}{l}\mathrm{Huh}^{10} \\
\text { RCT }\end{array}$ & 2008 & 57 & $\begin{array}{l}20 \mathrm{~cm} \mathrm{H}_{2} \mathrm{O} \\
\text { Prior recruitment using } \\
\text { pressure control to a } \\
\text { maximum of } 55 \mathrm{~cm} \mathrm{H}_{2} \mathrm{O}\end{array}$ & $\begin{array}{l}1 \mathrm{~cm} \mathrm{H}_{2} \mathrm{O} \\
\quad \text { every } 30 \mathrm{~s}\end{array}$ & $\begin{array}{l}\mathrm{S}_{\mathrm{pO}_{2}} \text { and static } \\
\text { compliance }\end{array}$ & $\begin{array}{l}\text { PEEP level above the } \\
\text { level that caused } \\
\text { an } \mathrm{S}_{\mathrm{pO}_{2}} \text { decrease of } \\
2 \% \text { and a decrease } \\
\text { in static compliance }\end{array}$ & $\begin{array}{l}\text { Initial improvement in } \\
\text { oxygenation; no } \\
\text { difference in respiratory } \\
\text { mechanics and patient } \\
\text { outcomes }\end{array}$ \\
\hline $\begin{array}{l}\text { Hodgson }^{11} \\
\text { RCT }\end{array}$ & 2011 & 20 & $\begin{array}{l}25 \mathrm{~cm}_{2} \mathrm{O} \\
\text { Prior recruitment using } \\
\text { pressure control to a } \\
\text { maximum of } 50 \mathrm{~cm} \mathrm{H}_{2} \mathrm{O}\end{array}$ & $\begin{array}{l}2.5 \mathrm{~cm} \mathrm{H}_{2} \mathrm{O} \\
\text { every } 3 \mathrm{~min}\end{array}$ & $\mathrm{~S}_{\mathrm{pO}_{2}}$ & $\begin{array}{l}2.5 \mathrm{~cm} \mathrm{H}_{2} \mathrm{O} \text { above } \\
\text { the level where } \\
\mathrm{S}_{\mathrm{pO}_{2}} \text { decreased by } \\
\geq 1 \% \text { of } \\
\text { maximum }\end{array}$ & $\begin{array}{l}\text { Greater amelioration in } \\
\text { some systemic cytokines; } \\
\text { improved oxygenation and } \\
\text { lung compliance over } \\
7 \text { days; no difference in } \\
\text { other clinical outcomes }\end{array}$ \\
\hline Fengmei $^{12}$ & 2011 & 23 & $\begin{array}{l}20 \mathrm{~cm} \mathrm{H}_{2} \mathrm{O} \\
\text { Prior recruitment using } \\
\text { sustained inflation of } 40 \\
\mathrm{~cm} \mathrm{H}_{2} \mathrm{O} \text { for } 30 \mathrm{~s}\end{array}$ & $\begin{array}{l}2 \mathrm{~cm} \mathrm{H}_{2} \mathrm{O} \\
\quad \text { every } 20 \mathrm{~min}\end{array}$ & $\begin{array}{l}\mathrm{P}_{\mathrm{aO}_{2}} / \mathrm{F}_{\mathrm{IO}_{2}}, \\
\mathrm{~V}_{\mathrm{D}} / \mathrm{V}_{\mathrm{T}}, \text { static } \\
\text { compliance }\end{array}$ & $\begin{array}{l}\text { Optimal considered } \\
\text { the highest level of } \\
\text { compliance } \\
\text { combined with the } \\
\text { lowest } \mathrm{V}_{\mathrm{D}} / \mathrm{V}_{\mathrm{T}}\end{array}$ & $\begin{array}{l}\text { Observations only during } \\
\text { PEEP titration; best } \\
\text { compliance was slightly } \\
\text { lower than lowest } \mathrm{V}_{\mathrm{D}} / \mathrm{V}_{\mathrm{T}}\end{array}$ \\
\hline
\end{tabular}

$\overline{\mathrm{RCT}}=$ randomized controlled trial

$\mathrm{V}_{\mathrm{D}} / \mathrm{V}_{\mathrm{T}}=$ ratio of dead space to tidal volume

$\mathrm{P}_{\mathrm{tp}}$ limit of $25-27 \mathrm{~cm} \mathrm{H}_{2} \mathrm{O}$ has been suggested in current literature, ${ }^{15,19}$ perhaps a $\mathrm{P}_{\mathrm{tp}}$ limit of $20 \mathrm{~cm} \mathrm{H}_{2} \mathrm{O}$ is more appropriate?

\section{Gas Exchange}

The observation made by Rodriguez and colleagues, ${ }^{6}$ of a good correlation between expiratory $\mathrm{P}_{\mathrm{tp}}$ and best $\mathrm{C}_{\mathrm{RS}}$ related to $\mathrm{P}_{\mathrm{aO}}$, suggests a benefit to using this approach, but best $\mathrm{C}_{\mathrm{RS}}$ resulted in a negative $\mathrm{P}_{\mathrm{tp}}$ in 4 patients, which significantly decreased $\mathrm{P}_{\mathrm{aO}_{2}}$. When looking at the individual patient data, it seems that even the addition of $2 \mathrm{~cm} \mathrm{H}_{2} \mathrm{O}$ above the level of best $\mathrm{C}_{\mathrm{RS}}$ (as described in some of the methods from the above Table ${ }^{9,11}$ ) would still result in a negative $\mathrm{P}_{\mathrm{tp}}$ for 3 out of the 4 patients.

The $V_{D} / V_{T}$ at best $C_{R S}$ and optimal end-expiratory $P_{t p}$ was highly correlated. It may appear that setting PEEP according to best $\mathrm{C}_{\mathrm{RS}}$ may result in a lower $\mathrm{P}_{\mathrm{aO}_{2}}$ with a negative $P_{t p}$ leaving the patient at risk of atelectasis, but most likely would not cause overdistention (worsening
$\mathrm{V}_{\mathrm{D}} / \mathrm{V}_{\mathrm{T}}$ ). Should we be worried about a lower $\mathrm{P}_{\mathrm{aO}}$ ? It is well known that better oxygenation does not imply improved outcomes. ${ }^{2-4}$

In a recent study published in ResPiRAtory CARE, $\mathrm{P}_{\mathrm{aO}_{2}} / \mathrm{F}_{\mathrm{IO}_{2}}$, $\mathrm{V}_{\mathrm{D}} / \mathrm{V}_{\mathrm{T}}$, and $\mathrm{C}_{\mathrm{RS}}$ were monitored during a decremental PEEP titration (methods listed in the above Table ${ }^{12}$ ). There was a significant improvement in $\mathrm{P}_{\mathrm{aO}_{2}} / \mathrm{F}_{\mathrm{IO}_{2}}$ at the starting PEEP of $20 \mathrm{~cm} \mathrm{H}_{2} \mathrm{O}$, which steadily declined but maintained significance at the same level that $\mathrm{V}_{\mathrm{D}} / \mathrm{V}_{\mathrm{T}}$ and $\mathrm{C}_{\mathrm{RS}}$ significantly improved (mean PEEP level of $12 \mathrm{~cm} \mathrm{H}_{2} \mathrm{O}$ ). Significant improvement in $\mathrm{P}_{\mathrm{aO}_{2}} / \mathrm{F}_{\mathrm{IO}_{2}}$ and $\mathrm{V}_{\mathrm{D}} / \mathrm{V}_{\mathrm{T}}$ was lost at a mean PEEP level of $10 \mathrm{~cm} \mathrm{H}_{2} \mathrm{O}$, whereas $\mathrm{C}_{\mathrm{RS}}$ continued to improve. However, PEEP was adjusted every 20 min, which may yield different results. Compared to the current study by Rodriguez and colleagues, $\mathrm{V}_{\mathrm{D}} / \mathrm{V}_{\mathrm{T}}$ and $\mathrm{C}_{\mathrm{RS}}$ trended similarly, whereas $\mathrm{P}_{\mathrm{aO}}$ trended slightly differently, most likely due to the starting PEEP of $30 \mathrm{~cm} \mathrm{H}_{2} \mathrm{O}$ used in the study. Regardless of trending differently, both studies demonstrated that the best $\mathrm{C}_{\mathrm{RS}}$ did not result in the best oxygenation. 


\section{Decremental PeEP Titration: A Step Away From the Table}

\section{Future Direction}

The use of esophageal pressure measurements as a guide for mechanical ventilation is a relatively new concept, requires the insertion of a catheter, and staff must be trained to interpret the observations made with the catheter. The technique for esophageal pressure measurement is well described and consistent with current research. This is feasible in an ICU environment with proper education and supportive staff. The decremental PEEP titration seems more attractive, as it requires only the ability to monitor compliance over time, of which all modern ventilators are capable, and requires less experience to perform properly. However, the question still remains: which method for performing the decremental PEEP titration is best?

Future randomized controlled studies powered for demonstrating a mortality benefit need to be done to determine once and for all whether these methods to individualize ventilation will improve outcomes in patients with ARDS, compared to current standards of practice. The decremental PEEP titration method has become fragmented in the literature, and could also benefit from observational research comparing methods. What seems to be promising is the desire to look up from under the "table," and move forward toward an individualized approach to mechanical ventilation.

Thomas Piraino RRT Respiratory Therapy Services St Joseph's Healthcare Hamilton, Ontario Canada and

Department of Anesthesia Faculty of Health Sciences McMaster University Hamilton, Ontario Canada

\section{REFERENCES}

1. Ashbaugh D, Petty T, Bigelow D, Harris T. Continuous positivepressure breathing (CPPB) in adult respiratory distress syndrome. J Thorac Cardiovas Surg 1969;57:31-41.

2. The Acute Respiratory Distress Syndrome Network. Ventilation with lower tidal volumes as compared with traditional tidal volumes for acute lung injury and the acute respiratory distress syndrome. N Engl J Med 2000;342(18):1301-1308.

3. Brower R, Lanken P, MacIntyre N, Matthay M, Morris A, Ancukiewicz M, et al. NHLBI ARDS Clinical Trials Network. Higher versus lower

The author has disclosed a relationship with CareFusion.

Correspondence: Thomas Piraino RRT, Respiratory Therapy Services, St Joseph's Healthcare, 50 Charlton Avenue East, Hamilton, Ontario Canada, L8N4A6. E-mail: piraino@mcmaster.ca.

DOI: $10.4187 /$ respcare. 02453 positive end-expiratory pressure in patients with the acute respiratory distress syndrome. N Engl J Med 2004;351(4):327-336.

4. Meade M, Cook D, Guyatt G, Slutsky A, Arabi Y, Cooper D, et al. Lung Open Ventilatory Study Investigators. Ventilation strategy using low tidal volumes, recruitment maneuvers, and high positive end-expiratory pressure for acute lung injury and acute respiratory distress syndrome: a randomized controlled trial. JAMA 2008;299(6): 637-645.

5. Dasenbrook EC, Needham DM, Brower RG, Fan E. Higher PEEP in patients with acute lung injury: a systematic review and meta-analysis. Respir Care 2011;56(5):568-575

6. Rodriguez PO, Bonelli I, Setten M, Attie S, Madorno M, Maskin LP, Valentini R. Transpulmonary pressure and gas exchange during decremental PEEP titration in pulmonary ARDS patients. Respir Care 2013;58(5):754-763.

7. Borges J, Okamoto V, Matos G, Caramez M, Arantes P, Barros F, et. al. Reversibility of Lung Collapse and Hypoxemia in Early Acute Respiratory Distress Syndrome. Am J Respir Crit Care Med 2006; 174(3):268-278.

8. Girgis K, Hamed H, Khater Y, Kacmarek RA. decremental PEEP trial identifies the PEEP level that maintains oxygenation after lung recruitment. Respir Care 2006;51(10):1132-1139.

9. Gernoth C, Wagner G, Pelosi P, Luecke T. Respiratory and haemodynamic changes during decremental open lung positive end-expiratory pressure titration in patients with acute respiratory distress syndrome. Crit Care 2009;13(2):R59.

10. Huh JW, Jung H, Choi HS, Hong, SB, Lim CM, Koh Y. Efficacy of positive end-expiratory pressure titration after the alveolar recruitment manoeuvre in patients with acute respiratory distress syndrome. Crit Care 2009;13(1):R22.

11. Hodgson CL, Tuxen DV, Davies AR, Bailey MJ, Higgins AM, Holland AE, et al. A randomised controlled trial of an open lung strategy with staircase recruitment, titrated PEEP and targeted low airway pressures in patients with acute respiratory distress syndrome. Crit Care 2011;5(3):R133.

12. Fengmei G, Jin C, Songqiao L, Congshan Y, Yi Y. Dead space fraction changes during peep titration following lung recruitment in patients with ARDS. Respir Care 2012;57(10):1578-1585.

13. Tugrul S, Cakar N, Akinci O, Ozcan PE, Disci R, Esen F, et al. Time required for equilibration of arterial oxygen pressure after setting optimal positive end-expiratory pressure in acute respiratory distress syndrome. Crit Care Med 2005;33(5):995-1000.

14. Talmor D, Sarge T, O’Donnell C, Ritz R, Malhotra A, Lisbon A, Loring S. Esophageal and transpulmonary pressures in acute respiratory failure. Crit Care Med 2006;34(5):1389-1394.

15. Talmor D, Sarge T, Malhotra A, O'Donnell C, Ritz R, Lisbon A, et al. Mechanical ventilation guided by esophageal pressure in acute lung injury. N Engl J Med 2008;359(20):2095-2104.

16. Loring SH, O'donnell CR, Behazin N, Malhotra A, Sarge T, Ritz R, et al. Esophageal pressures in acute lung injury: do they represent artifact or useful information about transpulmonary pressure, chest wall mechanics, and lung stress? J Appl Physiol 2010;108(3):515-522.

17. Piraino T, Cook DJ. Optimal PEEP guided by esophageal balloon manometry. Respir Care 2011;56(4):510-513.

18. Washko G, O'Donnell C, Loring S. Volume-related and volume-independent effects of posture on esophageal and transpulmonary pressures in healthy subjects. J Appl Physiol Mar 2006;100(3):753-758.

19. Chiumello D,Carlesso E, Cadringher P, Caironi P, Valenza F, Polli $\mathrm{F}$, et al. Lung stress and strain during mechanical ventilation for acute respiratory distress syndrome. Am J Respir Crit Care Med 2008;178(4):346-355.

20. Grasso S, Terragni P, Birocco A, Urbino R, Sorbo L, Filippini C, et al. ECMO criteria for influenza A (H1N1)-associated ARDS: role of transpulmonary pressure. Intensive Care Med 2012;38(3):395-403. 